\title{
A proposal for restructuring the layout of continuous freezing tunnels of fresh sausages
}

\section{Proposta de reestruturação de layout de túneis de congelamento contínuo de linguiças frescais}

\author{
Fernando Henrique Lermen ${ }^{1}$ (D), Rubya Vieira de Mello Campos² (D), Tânia Maria Coelho ${ }^{3}$, \\ Gustavo de Souza Matias ${ }^{2}$ (D), Márcia Elisa Soares Echeveste ${ }^{1}$ (D) \\ ${ }^{1}$ Universidade Federal do Rio Grande do Sul, Porto Alegre, RS, Brasil. \\ E-mail: fernando-lermen@hotmail.com; echeveste@producao.ufrgs.br \\ 2 Universidade Estadual de Maringá, Maringá, PR, Brasil. E-mail: rubyadmc@hotmail.com; gusmatias@gmail.com \\ ${ }^{3}$ Universidade Estadual do Paraná, Campo Mourão, PR, Brasil. E-mail: coelho_tania@yahoo.com
}

How to cite: Lermen, F. H., Campos, R. V. M., Coelho, T. M., Matias, G. M., \& Echeveste, M. E. S.,

2020. A proposal for restructuring the layout of continuous freezing tunnels of fresh sausages. Gestão \& Produção. 27(1), e2969. http://doi.org/10.1590/0104-530X2969-20

\begin{abstract}
Currently companies face a market extremely competitive, in this scenario, to achieve a significant profit margin, is essential to reduce costs and rework. This study was developed in the central food cooperative Aurora (Erechim- RS), in the continuous freezing tunnels, which are responsible for the biggest bottleneck of the company. The continuous freezing tunnels are very unstable, because the products are positioned on a rail, which can or cannot acquire the proper temperature for freezing, generating rework case do not meet the standards. Therefore, the objective was to restructure the current layout of continuous sausage freeze tunnels, based on temperature analyzes to evaluate compliance with the SAI-151-00 Internal Regulation, propose a new layout with static cages for the tunnels, present the budget for that change and to estimate a deadline to investment's payback. For this work were used approach methods qualitative and quantitative. As the purpose is classified as descriptive, methodological, and as to the means to be treated as field research, literature and case study. In order to perform the temperature analysis, the freezing conformity assessment methodology was used and the layout design methodology was used for the development of the new layout, in which a budget analysis was also developed according to the described methodology. With the completion of work was possible to developed a proposal for a new layout that will double capacity of freezing tunnels and meet all applicable standards. Also found through a budget analysis in less than five days of production in fresh pork the expenses will be paid off.
\end{abstract}

Keywords: Layout; Planning and production control; Physical arrangement; Food industry.

Resumo: As empresas enfrentam um mercado extremamente competitivo, diante deste cenário, para manterem-se ativas atingindo uma margem de lucro significativa é essencial reduzir os custos e o retrabalho. O presente estudo foi desenvolvido na Cooperativa Central Aurora Alimentos de Erechim - RS no setor de túneis e expedição. Os túneis de congelamento contínuo da empresa são responsáveis pelo maior gargalo do setor, atribui-se isso pela sua instabilidade, pois os produtos que são posicionados no trilho deveriam atingir a temperatura adequada de congelamento e normalmente não atingem, gerando assim retrabalho caso não obedeçam às normas estabelecidas para o setor. Sendo assim, o objetivo foi reestruturar o layout atual dos

Received Apr. 19, 2016 - Accepted Sept. 4, 2017

Financial support: CAPES Foundation.

This is an Open Access article distributed under the terms of the Creative Commons Attribution License, which permits unrestricted use, distribution, and reproduction in any medium, provided the original work is properly cited. 
túneis de congelamento contínuo de linguiças, baseado nas análises de temperatura para avaliar a conformidade com a Normativa Interna SAI-151-00, propor um novo layout com gaiolas estáticas para os túneis, apresentar o orçamento dessa mudança e estimar um prazo para a quitação do mesmo. Foram utilizados os métodos de abordagem quantitativo e qualitativo. Quanto aos fins classifica-se como descritiva e metodológica, e quanto aos meios classifica-se como pesquisa de campo, bibliográfica e estudo de caso. Para a realização das análises de temperatura utilizou-se a metodologia de avaliação de conformidade de congelamento e para o desenvolvimento do novo layout utilizou-se a metodologia de projeto de layout em que também se desenvolveu uma análise orçamentária conforme metodologia descrita. Foi possível desenvolver uma proposta de um novo layout que poderá dobrar a capacidade dos túneis de congelamento e assim vir a atender todas as normas vigentes. Também se constatou por meio de uma análise orçamentária que em menos de sete dias de produção nos frescais, as despesas poderão quitadas.

Palavras-chave: Layout; Planejamento e controle de produção; Arranjo físico; Indústria alimentícia.

\section{Introduction}

Among the different production chains that are part of the Brazilian agroindustrial system, the pig meat chain stands out for its great importance due to the changes in the characteristics of the products, the insertion in the international market, the technological gains and the sensitive changes in the scale of operation. The Brazilian pig breeding chain also stands out because it has a great articulation between the different agents that compose it, as well as the volume of investments injected into the activity (Gomes, 2002).

Refrigerator Aurora from Erechim II [FAER II], a unit of Aurora Alimentos, focuses on the slaughtering, cutting and industrialization of meat products in its complex and has products such as: pork cuts; salty hams; seasoned; lard; cooked sausage; cured salami; fresh sausages; smoked bacon; by-product; and guts.

Currently, all products made in the fresh sector (pork sausage, tempered, peasant, spicy, and chicken) are taken to the continuous freezing tunnels, which according to Salvador (1999) are the most unstable tunnels, since the products are positioned in a rail which may or may not have the proper temperature for freezing but is easy to handle for the product to be inserted or removed from the tunnels.

Currently, all products made in the fresh sector (pork sausage, tempered, peasant, spicy, and chicken) are taken to the continuous freezing tunnels, which according to Salvador (1999) are the most unstable tunnels, since the products are positioned in a rail which may or may not have the proper temperature for freezing but is easy to handle for the product to be inserted or removed from the tunnels.

The Cooperative Central Aurora Alimentos FAER II has demand and capacity of production of frescals, but does not have capacity of freezing in the tunnels. Therefore, the objective of this work was to restructure the current layout of the tunnels of continuous freezing of sausages, based on the temperature analyzes to evaluate the compliance with Internal Regulation SAI-151-00, to propose a new layout with static cages for the tunnels, present the budget for that change and estimate a deadline for the discharge of the change.

The present work is classified according to the Brazilian Association of Production Engineering (Abepro, 2008) in the area of Operations and Production Process Engineering and in the sub-area of Factory and Industrial Facilities: layout / physical arrangement. 
This study is justified by the fact that the continuous freezing tunnels are the biggest bottleneck of FAER II, and because they do not comply with the SAI-151-00 Internal Regulation, and there is a constant need for rework. Also due to the need for studies of layout restructuring for the academic, thus enabling the realization of studies in this area.

The work is structured in 7 sections. In the first one, the work was contextualized. The second presents the basic theory used for the development of the work. The third one presents the research methodology used. In the sequence, we present the literature review, composed by works with the same focus or similar. In the fifth section the presentation of the company studied is presented. The sixth contemplates the results obtained. In the seventh and last section the final considerations are presented.

\section{Theoretical background}

In this section, the necessary theory for the understanding of the study is presented.

\subsection{Layout}

Originally, the term "lay-out" refers to the physical arrangement of equipment. Today, the term generalizes itself, and its main objective is to present the best use of available space that results in a more effective processing, through shorter distance in the shortest time (Toledo, 2004, p. 8).

Layout of a corporate operation is concerned with the physical location of the transformation resources, that is, decides where to place all facilities, machines, equipment and production personnel (Slack et al., 1996).

Lustosa et al. (2011, p. 336) reported that the layout of a service facility determines the flow of customers and materials throughout the service delivery. Shingo (1996, p. 136) make some considerations regarding layout improvements:

Improving layout goes through several steps. Firstly, the machines must be arranged in correspondence with the processing flow of the product. Organizing the plant into sections according to the type of machine (ie. section of the presses or section of the lathes) is a measure that only increases the transport.

The following subtopics present the layout types, standards required for product placement in static freeze tunnels, and how to develop a layout design.

\subsubsection{Types of layout}

In this step a bibliographic review was carried out with different layout definitions, with the idea of several authors to evaluate the best option for the present work, presented in Table 1 in ascending chronological order.

Table 1. Layout types.

\begin{tabular}{ccc}
\hline Authors & Types of Layout & Definitions \\
\hline Slack et al. (1996) & Position Layout & $\begin{array}{c}\text { Suitable for very large products that } \\
\text { have problems to be moved }\end{array}$ \\
\hline
\end{tabular}




\begin{tabular}{|c|c|c|}
\hline Authors & Types of Layout & Definitions \\
\hline & Process Layout & $\begin{array}{c}\text { The needs and conveniences of the } \\
\text { transforming resources that constitute } \\
\text { the process in the operation denominate } \\
\text { the decision on the physical } \\
\text { arrangement }\end{array}$ \\
\hline & Cell Layout & $\begin{array}{l}\text { Indicated for the preselected products to } \\
\text { move to a specific part of the operation } \\
\text { (or cell) where each one meets its need }\end{array}$ \\
\hline & Product Layout & $\begin{array}{l}\text { It locates the productive resources } \\
\text { entirely according to the best } \\
\text { convenience of the resource that is } \\
\text { being transformed }\end{array}$ \\
\hline \multirow{4}{*}{$\begin{array}{l}\text { Gaither \& Frazier } \\
\qquad(2002)\end{array}$} & $\begin{array}{l}\text { Positional Layout (or by } \\
\text { Physical Position) }\end{array}$ & $\begin{array}{l}\text { Used when a product is bulky, large, } \\
\text { heavy or fragile, it also minimizes the } \\
\text { required amount of product movements }\end{array}$ \\
\hline & Process Layout & $\begin{array}{l}\text { It is customary in organizations that } \\
\text { produce a variety of custom products in } \\
\text { relatively small lots }\end{array}$ \\
\hline & Cell Layout & $\begin{array}{c}\text { Each cell is built to produce a single } \\
\text { family of parts (all with common features } \\
\text { that require the same type of machine } \\
\text { and similar configurations) }\end{array}$ \\
\hline & Product Layout & $\begin{array}{c}\text { It is designed to accommodate some } \\
\text { product designs and to allow a linear } \\
\text { flow of materials throughout the locality } \\
\text { where these products are }\end{array}$ \\
\hline \multirow{3}{*}{ Camarotto (2006) } & Position Layout & $\begin{array}{c}\text { It is characterized by a space } \\
\text { arrangement where the material to be } \\
\text { worked (part, part or item) remains } \\
\text { stationary as operators and equipment } \\
\text { move around it }\end{array}$ \\
\hline & Functional Layout & $\begin{array}{l}\text { It is characteristic of this type of } \\
\text { arrangement the groupings of similar } \\
\text { machines forming departments or } \\
\text { sectors of processes with nomenclature } \\
\text { quite common in the factories }\end{array}$ \\
\hline & Linear Layout & $\begin{array}{l}\text { The layout of the workstations follows } \\
\text { the sequence of product processing, } \\
\text { forming groupings of different equipment } \\
\text { and activities, keeping in common the } \\
\text { sequential processing of parts of a } \\
\text { product }\end{array}$ \\
\hline \multirow{3}{*}{$\begin{array}{l}\text { Lustosa et al. } \\
\qquad(2011)\end{array}$} & Product Layout & $\begin{array}{l}\text { It is the service executed in series, that } \\
\text { is, the same sequence of operations is } \\
\text { applied repetitively in large volumes }\end{array}$ \\
\hline & Process Layout & $\begin{array}{c}\text { Also known as functional layout, in which } \\
\text { the resources are organized according to } \\
\text { the function they exert in the productive } \\
\text { process }\end{array}$ \\
\hline & Position Layout & $\begin{array}{l}\text { It is one in which the customer does not } \\
\text { move throughout the productive process }\end{array}$ \\
\hline
\end{tabular}

Note: Source: Prepared by Authors. 
The definition of the Positional Layout proposed by Camarotto (2006) was chosen because it is more in line with the objective of the study, which is to insert static cages in continuous freezing tunnels.

A complementary factor in the decision to choose a type of layout is the movement of the factors of production that compete for the flow of the manufacture. The movement, for the construction of the layout, is separated according to Camarotto (2006), p. 81 in:

i. Material movement: the materials move from post to workstation and, in this displacement, undergo the changes that the productive processes cause in the part to obtain the finished product;

ii. Movement of man - in this case the man moves from work, and in each position performs an operation;

iii. Moving the equipment - the equipment moves to produce the operation, going through several jobs or following the product;

iv. Movement of man and material - both move. It happens, for example, in assembly lines, when man and material move simultaneously;

v. Movement of material and equipment - Man receives material and equipment, moving to the work station, as in the civil construction where the concrete goes to the work, with a concrete mixer;

saw. Movement of man and equipment - The material remains fixed, receiving the combined action of the other two factors of production. In the paving works there are several examples of this type of movement; and,

vii. Movement of man, machine and material - They are quite rare. This joint movement is not normally required.

\subsubsection{Standards for layout suitability}

The Regulatory Standard 31 of the Ministry of Labor and Employment of Ordinance No. 86 of March 3, 2005 (Brasil, 2005), which presents provisions on Occupational Safety and Health in Agriculture, Livestock, Forestry, Forestry and Aquaculture, governs that the containers must be disposed of such that the batteries are away from the walls $50 \mathrm{~cm}$ and 1 (one) meter from the ceiling or lighting system.

The same Regulatory Standard 31 directs that the packages in the cages must be at a height of the floor of $50 \mathrm{~cm}$ to not run risk of contamination of the products. With these measures the layout was restructured by adapting the tunnels to the norm.

\subsubsection{Layout project}

The design of the layout itself will take as information the information about the process, materials and equipment (Camarotto, 2006).

This information is expressed in Table 2. 
Table 2. Data needed for the Layout Project.

\begin{tabular}{ll}
\hline Necessary information & Detailed information \\
\hline & - Size, Product; \\
General information about the company & - Current and future Production Level; \\
& - Land and capital involved; and, \\
& - Types of raw material and general \\
& conditions of the process \\
\hline Informations about the product & - Physical and geometric characteristics; \\
& - Handling and storage; \\
& - Quality conditions; and, \\
& - Component parts \\
Information about the process & - Operation and assembly diagrams; \\
& - Worksheets and operating times; \\
Information about people and ancillary & - Stocks and transport; and, \\
services & - Other information \\
\hline \multirow{3}{*}{ Equipment Information } & - Staff required; and, \\
& - Administrative and support services \\
\hline General financial information & - Complete list of equipment and templates; \\
& - Operation characteristics; and, \\
\hline - Cost of equipment
\end{tabular}

Note: Source: Adapted from Camarotto (2006).

Camarotto (2006), p. 17 reported that there are three steps for the development of a layout:

i. Sizing of production factors: one has the first idea about the flat surface to be occupied by the plant, without any idea about the final format of the factory or the physical relations between the areas;

ii. Relationships of production factors: analysis and decision-making about circulation space between production and support sectors and process modifications will be elaborated; and,

iii. Layout Detail: involves the specification of all elements that will contribute to the operation of the industrial unit.

\subsection{Freezing tunnels}

There are several types of freezing tunnels, but for this work tunnels of continuous and static freezing will be defined.

Continuous freezing tunnels are considered to be the most unstable because the products are positioned on a track, which may or may not acquire the proper temperature for freezing, but is easily manipulated for the product to be inserted or removed from the tunnels (Salvador, 1999).

Static freeze tunnels are places where products are packed in cages or cars while freezing. The Ministry of Agriculture, Livestock and Supply (MAPA) (Brasil, 2007) reports that static freeze tunnels provide versatility for processing products of different sizes, species and presentations, including individually frozen products as well as large species, however, need of larger area. 


\subsection{Pork processing}

The processing of pork must be done in an air-conditioned environment $\left(12{ }^{\circ} \mathrm{C}\right)$, starting with boning and separating the cuts for specific purposes, such as: shank, filezinho, palta, lean and fat cut, filet steak, duckling, soft thigh, over pallet, belly and rib. We still find the following parts in pigs: bacon, offal (feet, ears, muzzles, tails, heart, kidney and trachea), head and chin (Sarcinelli et al., 2007).

The products produced in the tunnels under study are pork sausages which, according to Ferreira et al. (2009) in general, is the processed meat product made from the meat of one or more species of butchers, cooked or uncooked, whether or not smoked or not, whether or not cured, whether or not containing added fats or bacon, added with ingredients and embedded in natural or artificial casings.

\section{Literature review}

In this section, the research sought to focus on works that had the objective of proposing or changing layout in companies. The search for these works was done in annals of national events, theses, dissertations, magazines and national and international databases of Production Engineering. The period of the work is from 1998 to 2013 , some are relatively old works but of great importance for the academic. The evaluated works appear in ascending chronological order.

Fraser (1998) discusses in his work parameters for the choice, design and management of refrigeration systems, making a comparison between three different systems of refrigeration of fresh fruits and vegetables to forced convection, being: horizontal airflow tunnel, flow of vertical air and vertical/horizontal serpentine. Initially, the advantages and disadvantages of each type of system are discussed. Flowcharts describe the operation of each system. After this the relationship between the air temperature and the cooling time required to reduce the temperature of fresh vegetables to certain temperature fractions is shown. Finally, it is concluded that forced convection cooling is the most flexible and efficient method for the rapid cooling of fresh products, however the systems must be rigorously designed.

Tortorella (2006) developed in his dissertation a work with the objective of using multicriteria decision support tools in layout planning systematics, in which he put into practice the methodology of multicriteria analysis in the selection of layout alternatives in a branch company which needed to increase its manufacturing plant to incorporate new equipment and optimize the flow of materials. With the accomplishment of the work generated nine alternatives of different macro-layout being evaluated the best general alternative in relation to seven criteria of evaluation.

Silva (2009) developed in his thesis an easy-to-use model that helps people involved in the design of a physical arrangement, the model uses tools and concepts of lean production to analyze and design the new layout, it also incorporates the implementation methodology of the arrangement physical design in situations with the factory in operation, finally, this work presents the methodology $3 \mathrm{P}$ Kaizen, a methodology of design of industrial layout developed by Toyota and used in situations of design of new factories or new production lines.

Soares et al. (2011) presented in their study a proposal of computational simulation of the restructuring of a cellular layout in order to evaluate the reduction of inventories in process, increase of productivity, reduction of lead time and adequacy of the labor force in the production cell. The main contribution of the use of the simulation in this 
study was that in addition to the expected improvements in the performance of the manufacturing cell due to the application of the concepts of the Toyota Production System, such as reduction of operator idleness, reduction of WIP -process) and increased productivity, difficult to analyze in an analytical way, could be observed and understood through the simulation technique, which allowed a systemic understanding of the object of study as a whole.

Fernandes et al. (2013) developed a work that aimed to demonstrate small changes in the layout studied and extended the possibilities of using the spaces of the industry implementing a logical sequence of production, which eliminated the great times of location and displacement of parts allowing a greater control over the progress of production, given that the industry in question does not produce in series, but products totally different from each other according to the customer's specification, the changes have been satisfactory and that changes such as the developed one can be used in several industrial segments of non-serial products provided that good studies are done on the product, production, times, methods and layout.

\section{Material and methods}

The qualitative and quantitative approaches were used to carry out this work. The qualitative method for carrying out research in the area of layout change, and the quantitative to perform statistical analysis of the results of the tests of temperature in the exit of the boxes in the tunnels of continuous freezing, layout budget and discharge of the cost.

Regarding the ends, the research is classified as descriptive, since from the studies a new layout proposal was presented. Methodological, since the adapted steps of Vieira (2007) were used to carry out the measurements of temperature in the boxes and adapted steps of Camarotto (2006) to propose the new layout and applied research to have the purpose of solving the problems of freezing the sausages swine at Aurora Foods.

As for the means, the research is classified as field research, because it was developed in FAER II, bibliographic research, by the use of information published in printed and digital materials and case study, because a real case was studied where the temperature obtained was evaluated in several boxes in the tunnels to verify the absence of cold capacity.

For the accomplishment of the work were used, an acrylic drawing board, A4 sheets with Table 1, black ballpoint pen and a digital thermometer for low temperatures with skewer and armored cable - Incoterm. We also used software such as Microsoft Visio and Excel.

Box temperature measurements were carried out in the continuous freezing tunnels 1 and 2, each tunnel having five rails with twenty cages, in which adapting the study by Vieira (2007) analyzed the temperatures in the ten rails in cages listed (1st, 10 and 20) where three boxes per cage were removed (at the top, at the center and at the bottom) evaluating the temperatures at ten points as shown in the fill model in Table 3. 
Table 3. Worksheet for collecting temperature data in Continuous Freezing Tunnels.

\begin{tabular}{|c|c|c|c|c|c|c|c|c|c|}
\hline & \multicolumn{9}{|c|}{ Trail: Date and Time of Arrival: $00 \mathrm{~h} 00 \mathrm{~min}$} \\
\hline & \multicolumn{9}{|c|}{ Date and Time of Exit: $00 \mathrm{~h} 00 \mathrm{~min}$ Duration in the Tunnel: $00 \mathrm{~h} 00 \mathrm{~min}$} \\
\hline & \multicolumn{3}{|c|}{ Cage 1 - Position $1^{\text {a }}$} & \multicolumn{3}{|c|}{ Cage 2 - Position $10^{a}$} & \multicolumn{3}{|c|}{ Cage 3 - Position 20a } \\
\hline & $\begin{array}{l}\text { Higher } \\
\left({ }^{\circ} \mathrm{C}\right)\end{array}$ & $\begin{array}{l}\text { Center } \\
\left({ }^{\circ} \mathrm{C}\right)\end{array}$ & $\begin{array}{l}\text { Inferio } \\
\mathrm{r}\left({ }^{\circ} \mathrm{C}\right)\end{array}$ & $\begin{array}{l}\text { Higher } \\
\left({ }^{\circ} \mathrm{C}\right)\end{array}$ & $\begin{array}{l}\text { Center } \\
\left({ }^{\circ} \mathrm{C}\right)\end{array}$ & $\begin{array}{l}\text { Inferior } \\
\left({ }^{\circ} \mathrm{C}\right)\end{array}$ & $\begin{array}{l}\text { Higher } \\
\left({ }^{\circ} \mathrm{C}\right)\end{array}$ & $\begin{array}{l}\text { Center } \\
\left({ }^{\circ} \mathrm{C}\right)\end{array}$ & $\begin{array}{l}\text { Inferior } \\
\left({ }^{\circ} \mathrm{C}\right)\end{array}$ \\
\hline $\begin{array}{l}\text { Greater } \\
\text { Side } 1\end{array}$ & & & & & & & & & \\
\hline $\begin{array}{l}\text { Greater } \\
\text { Side } 2\end{array}$ & & & & & & & & & \\
\hline $\begin{array}{l}\text { Small } \\
\text { Side } 1\end{array}$ & & & & & & & & & \\
\hline $\begin{array}{l}\text { Small } \\
\text { Side } 2\end{array}$ & & & & & & & & & \\
\hline Center 1 & & & & & & & & & \\
\hline Center 2 & & & & & & & & & \\
\hline Side 1 & & & & & & & & & \\
\hline Side 2 & & & & & & & & & \\
\hline Side 3 & & & & & & & & & \\
\hline Side 4 & & & & & & & & & \\
\hline
\end{tabular}

Note: Source: Prepared by the authors.

Based on the results obtained, from the Table 3 the alert points for the continuous freezing points were found. From the data, a new layout was developed following the steps proposed by the methodology of Camarotto (2006), also meeting as norms cited in the Theoretical Framework, in which a Budgetary Assessment based on the methodology of Araújo (2010) arose in conjunction with the Maintenance of Aurora Food, was also designed together with the Industrial Advisory the time required for the production of costs for the development of the new provision.

\section{Description of the Company studied - Cooperative Central Aurora Alimentos}

The Company studied is part of the union of thirteen cooperatives that make up the system of a Central Food Cooperative, which provides approximately 26 thousand direct jobs and 8 thousand indirect jobs (Cooperativa Central Aurora Alimentos, 2015). Currently, FAER II operates with a slaughter plan for 1,675 pigs per day, with around 1300 employees working in three shifts, 24 hours a day.

The Frigorífico focuses on slaughter, cuts and industrialization of meat products, in its complex has products such as: cuts pork; salty hams; seasoned; lard; cooked sausage; cured salami; fresh sausages; smoked bacon; by-product; and guts. The commercialization of these products happens through three brands, being: Aurora; Peperi e; Noble. FAER II has as main market the most present national in the southern and southeastern states (Cooperativa Central Aurora Alimentos, 2015).

The sector is the Tunnels and Chambers where the continuous freezing tunnels 1 and 2 are arranged, responsible for the freezing of all products developed in the fresh sector.

The process is initiated on the tripartite, where the company works with the internal gut and release three other external ones (Tripigs, Brascase and Doremus) for the sector of Frescais (pork sausage, seasoned, peasant, spicy and of Chicken) which 
receive the cuts the FAER I, where in the fresh meat sector there are three inlets (Vemag 1, Vemag 2 and Handtmann), where the product is packed, made in the vacuum and carried in boxes in the continuous cages as shown in Figure 1.

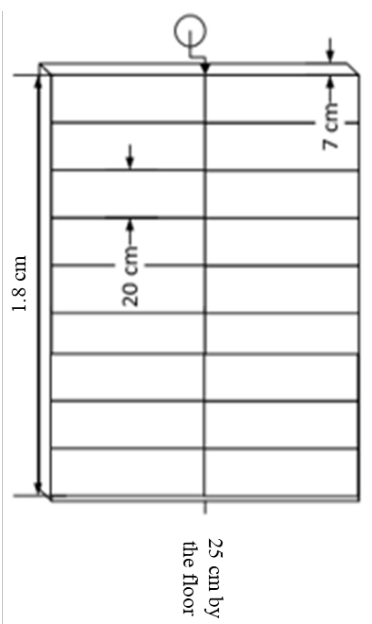

Figure 1. Continuous Freezing Cage. Source: Prepared by Authors.

Once the cage is filled with the $1810 \mathrm{~kg}$ sausage cartons, it is then subjected to the continuous freeze tunnels as shown in Figure 2, where each of the 10 rails contains twenty cages represented by the circles with $\mathrm{x}$.

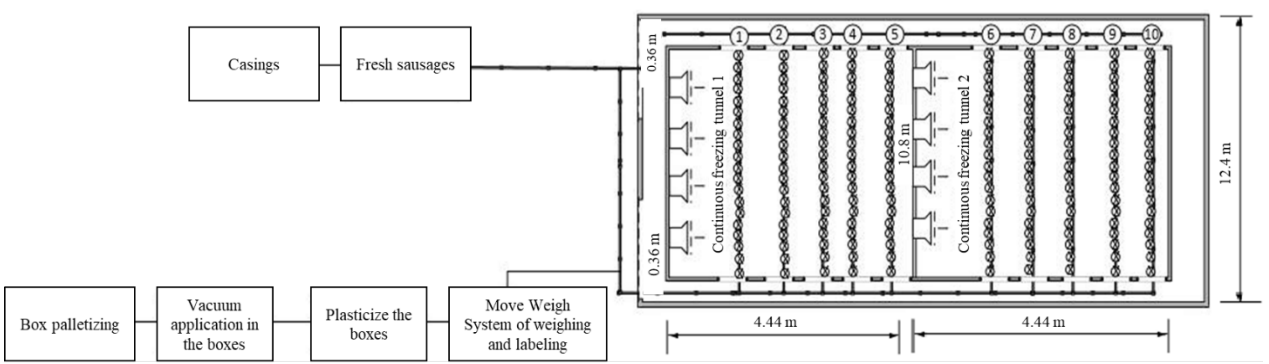

Figure 2. Operation of Continuous Freezing Tunnels. Source: Prepared by Authors.

FAER II follows a standard for Tunnels and Chambers, and SAI-151-00 Internal Regulation of September 27, 2010, which rules that frozen sausages should be removed from tunnels with a maximum temperature of $-12{ }^{\circ} \mathrm{C}$, the which temperature measurements should be taken at the exit of the tunnels, if they do not meet the standard, the quality control hijacks the product and the same returns to the tunnels for the same procedure.

The operation of the continuous freezing tunnels 1 and 2 is given by the four freezing fans in each tunnel as shown in Figure 2, each of which is responsible for feeding the low temperature of $-35{ }^{\circ} \mathrm{C}$ from the 5 rails per tunnel. The cages are arranged in the rails as shown in Figure 3. 


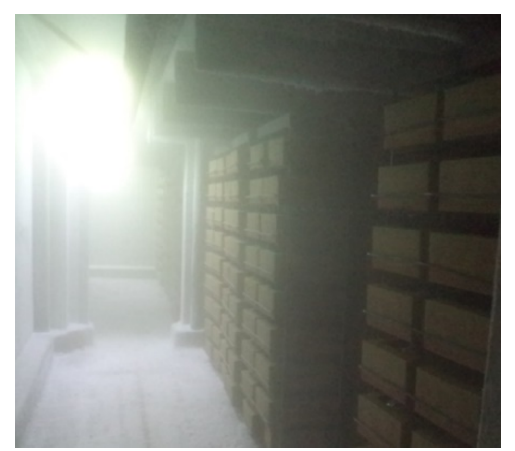

Figure 3. Layout of cages in continuous freezing tunnels. Source: Prepared by Authors.

As the rail is emptied, the boxes are taken to the Weighing and Labeling System MWS (Move Weigh System) and another operator resets the cages to the rails. The box withdrawal and weighing system is shown in Figure 4.

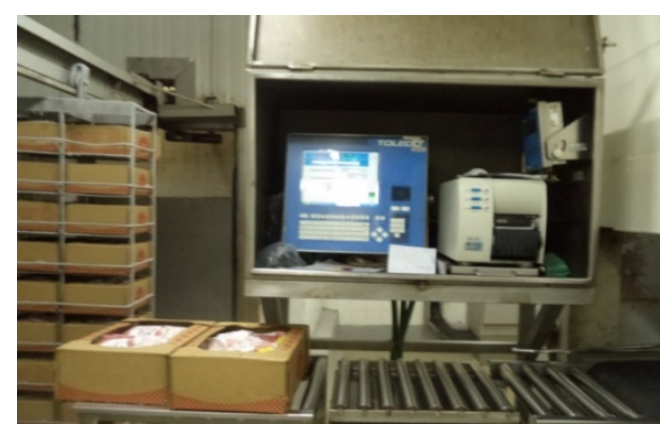

Figure 4. MWS (Move Weigh System) System of Weighing and Labeling. Source: Prepared by Authors.

After passing through the MWS system the product is taken to the palletization and in the sequence for the Expedition.

\section{Results and discussions}

This section is divided into three stages, the temperature evaluation for the proof of the problem, the design of a new layout, and the budget evaluation of the project.

\subsection{Temperature rating}

Initially, a temperature analysis was carried out at the points of the freezing tunnels 1 and 2, the measurements are shown in Appendix A in Tables 1 to 10, which show the results of the analyzes performed on rails 1 to 10 . These temperature data were measured from the application based on the methodology of Vieira (2007), which are causes of the problems presented in Table 4. 
Table 4. Concluding analyzes of the causes of the problems.

\begin{tabular}{cl}
\hline Tracks & \multicolumn{1}{c}{ Temperature analysis } \\
\hline $\mathbf{1}$ & $\begin{array}{l}\text { It did not present temperature dysfunctions because it remained below the } \\
\text { ventilators for 23h30min, but presented a layer of ice on top of the boxes. }\end{array}$ \\
\hline $\mathbf{2}$ & $\begin{array}{l}\text { It presented temperatures below the norm in the 10th and 20th cage, because the } \\
\text { freezing time was less than the 1st and did not correctly circulate the cold air } \\
\text { currents. }\end{array}$ \\
\hline $\mathbf{3}$ & $\begin{array}{l}\text { It does not meet the standards at some points in the 10th and 20th cages because } \\
\text { they are the last to be laid out in the tunnels. }\end{array}$ \\
\hline $\mathbf{4}$ & $\begin{array}{l}\text { It did not present temperature dysfunctions. } \\
\text { It did not present temperature dysfunctions, but presented a layer of ice on top of } \\
\text { the boxes. }\end{array}$ \\
\hline $\mathbf{6}$ & $\begin{array}{l}\text { It presented temperature dysfunctions in all cages measured, by the low freezing } \\
\text { time of 10h10min. }\end{array}$ \\
\hline $\mathbf{8}$ & $\begin{array}{l}\text { All cages measured have dysfunctions because it is a rail that has not acquired the } \\
\text { temperature of the tunnel. }\end{array}$ \\
\hline $\mathbf{9}$ & $\begin{array}{l}\text { The 20th cage did not respond to the temperature because the freezing time was } \\
\text { shorter than the others of 10h40min. }\end{array}$ \\
\hline $\mathbf{1 0}$ & $\begin{array}{l}\text { It did not present temperature dysfunctions. } \\
\text { The 10th presented dysfunctions during the low freezing time of 13h30min. }\end{array}$
\end{tabular}

Note: Source: Prepared by the authors.

Evaluating Table 4, it was possible to conclude that trails 2, 6, 7, 8 and 10 presented dysfunctions of the measured temperatures, thus failing to comply with the internal standard SAI-151-00. In rails 1 and 5 there are problems with excess ice formation in the sausage boxes, because they are below the fans, with overweight problems occurring which, in order to pass through the MWS System, the sausages must be removed from the boxes and the ice removed. continue the process.

With the analyzes developed, it was noted the need to develop a new layout as presented below.

\subsection{Layout project}

As indicated in the previous step, the continuous freezing tunnels have many problems, and the static cages are not meeting the standards, because they are $25 \mathrm{~cm}$ from the ground and do not have the temperatures that meet the norm, due to the capacity of the tunnels to be 40 thousand boxes per day, but they exceed the capacity with 52 thousand boxes, due to that, it is necessary to develop a new layout in this case, it will be adapted the methodology of Camarotto (2006).

Initially, to solve these problems, a static cage was developed, in Hack format, where the cage, because it is still, loses heat more easily, this static cage is shown in Figure 5. 


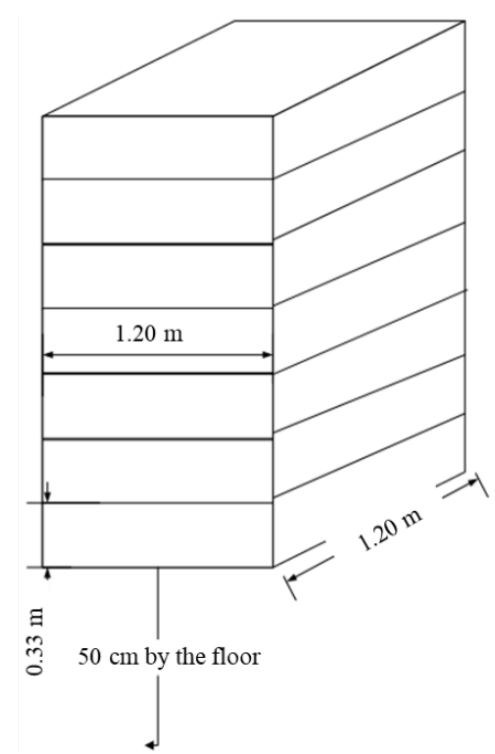

Figure 5. Static Cage in Hack format. Source: Prepared by Authors.

The static cage shown in Figure 5 meets the standards because it has a distance of $50 \mathrm{~cm}$, and also has a capacity greater than the continuous, since it has 84 boxes per cage, it has seven floors, with a capacity of twelve boxes per floor. They can behave in the new layout that meets the standards $50 \mathrm{~cm}$ away from the walls and $1 \mathrm{~m}$ away from the ceiling. The proposed new layout is showned in Figure 6.

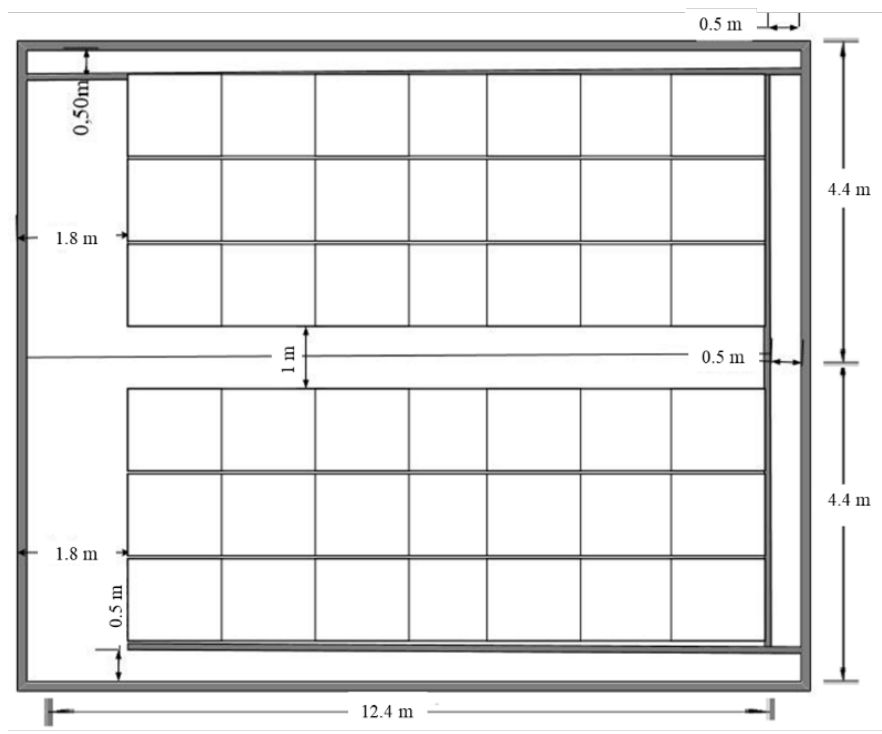

Figure 6. Proposal for a new Layout. Source: Prepared by Authors.

The new layout has a capacity of $35,280 \mathrm{~kg}$ every 12 hours in the tunnels, that is, it has a capacity of $70,560 \mathrm{~kg}$ per day, being twice as much as the current capacity in the tunnels of continuous freezing. 


\subsection{Financial evaluation}

To make possible the change of the new layout, a budget evaluation was developed based on Araújo's methodology (2010).

Initially, a budget was developed in conjunction with FAER II Maintenance, evaluating the costs required to apply the new layout proposal, this budget is presented in Table 5.

Table 5. Proposed budget for applying the new layout.

\begin{tabular}{|c|c|c|}
\hline Material required & Unit Value $(\mathbf{R} \$)$ & $\begin{array}{l}\text { Total Value } \\
\quad(R \$)\end{array}$ \\
\hline $\begin{array}{l}42 \text { Cages Fire-galvanized manufactured in profile } U \\
\text { sheet with a capacity of } 84 \text { boxes of } 10 \mathrm{~kg} \text { of } 7 \text { floors }\end{array}$ & $3,500.00$ & $147,000.00$ \\
\hline $\begin{array}{l}1 \text { Traction Electric Forklift Pt } 1616 \text { Paletrans with } \\
\text { capacity of } 1600 \mathrm{~kg} \text { with lifting of } 1600 \mathrm{~mm}\end{array}$ & $21,360.00$ & $21,360.00$ \\
\hline Remove continuous cages from tunnels & $12,500.00$ & $12,500.00$ \\
\hline \multirow[t]{2}{*}{$\begin{array}{l}\text { Renovations of tunnels for capacity of new static } \\
\text { cages }\end{array}$} & $26,200.00$ & $26,200.00$ \\
\hline & Total (R\$) & $207,060.00$ \\
\hline
\end{tabular}

Note: Source: Prepared by the authors.

From the survey carried out and shown in Table 5, a total cost of $\mathrm{R} \$ 207.060,00$ was reached, which will be the cost required to develop the new layout.

Following this, a survey was carried out together with the FAER II Industrial Assessment to evaluate how many days of production of the Frescals (pork sausages of $1 \mathrm{~kg}$ ) would take away the costs of changing the layout, in relation to the profit per product, these cost analyzes are presented in Table 6.

Table 6. Budget for discharge of costs with the new layout by the production in the fresh ones.

\begin{tabular}{lccc}
\hline Product of Frescals & $\begin{array}{c}\text { Profit of the Sale } \\
(\mathbf{R} \$)\end{array}$ & $\begin{array}{c}\text { Productivity/day } \\
(\mathbf{k g})\end{array}$ & $\begin{array}{c}\text { Total profit/day } \\
(\mathbf{R} \$)\end{array}$ \\
\hline Swine Sausage $1 \mathrm{~kg}$ & 2.27 & 13.200 & $29,964.00$ \\
\hline
\end{tabular}

Note: Source: Prepared by the authors.

With analysis of Table 6 it was possible to realize that in less than seven days of work in the Frescais the costs of modification of layout are removed.

\section{Conclusions}

With the realization of the work it was possible to realize that the tunnels are responsible for a bottleneck of the company and for the analyzes of temperatures. It is concluded that there are points in the tunnels that do not conform to SAI-151-00, and when the lots do not meet, they are reserved by Quality Control, and sent back to the tunnels, generating rework for the company.

From the new layout the capacity of the tunnels can double, freeing the increase of the production and being able to meet the demand, being possible to freeze daily 
$70.560 \mathrm{~kg}$. A budget for the new layout was made, which will be paid in less than seven days of production of frescals.

Some improvements are also proposed in the tunnels, with openings on the sides of the boxes to increase the access of the cold air and to increase the speed of freezing of the products and also to put curtains of cold air in the entrance and exit of the tunnels to maintain the internal temperature.

In the future, work will be followed in contact with the engine room to assess whether the temperature of the tunnels meets the increase in productivity, also with the frescals sector to assess whether they have the capacity to double productivity.

\section{References}

Associação Brasileira de Engenharia de Produção - ABEPRO. (2008). Áreas e subáreas de engenharia de produção. Rio de Janeiro: ABEPRO. Retrieved in 2015 November 22, from http://www.abepro.org.br/interna. asp? $p=399 \& m=424 \& s s=1 \& c=362$

Araújo, D. F. (2010). Análise da viabilidade econômica de novos projetos (Monografia de Conclusão de Curso). Universidade de Candido Mendes, Rio de Janeiro.

Brasil. Ministério do Trabalho e Emprego. (2005). Portaria No 86 de 03 de março de 2005. NR 31 - Segurança e Saúde no Trabalho na Agricultura, Pecuária, Silvicultura, Exploração Florestal e Aquicultura. Brasília, DF: Diário Oficial da República Federativa do Brasil. Retrieved in 2015 November 22, from http://portal.mte.gov.br/images/Documentos/SST/NR/NR31.pdf

Brasil. Ministério da Agricultura, Pecuária e Abastecimento. (2007). Manual de Procedimentos - Implantação de Estabelecimento Industrial de Produtos Frescos e Congelados. Brasilia: Ministério da Agricultura, Pecuária e Abastecimento. Retrieved in 2015 November 22, from http://www.aprendendoaexportar.gov.br/_pescados/ _pdf/Manualprocedimentospescado.pdf

Camarotto, J. A. (2006). Projeto de unidades produtivas. São Carlos: Departamento de Engenharia de Produção, UFSCar. Apostila.

Cooperativa Central Aurora Alimentos. (2015). História da cooperativa. Retrieved in 2015 November 20, from http://www.auroraalimentos.com.br

Fernandes, G., Strapazzon, R., \& Carvalho, A. D. P. (2013). Layout de empresas e seus benefícios. In: IIIXXX ENEGEP, Salvador. Encontro Nacional de Engenharia de Produção. Salvador, BA, Brasil.

Ferreira, A. C. B., Fonseca, L. M., \& Santos, W. L. M. (2009). Composição centesimal e aceitação de linguiça elaborada com reduzido teor de gordura e adicionada de concentrados proteicos de soro de leite. Ciência Rural, 39(1), 209-2014. http://dx.doi.org/10.1590/S0103-84782009000100032.

Fraser, H. (1998). Tunnel forced-air coolers for fresh fruits \& vegetables. Canada: Ministry of Agriculture, Food and Rural Affairs.

Gaither, N., \& Frazier, G. (2002). Administração da produção e operações (8. ed.). São Paulo: Pioneira Thomson Learning.

Gomes, M. F. M. (2002, Outubro). As cadeias agroindustriais da carne. In: BDMG Memória Viva. (Org.), Minas Gerais do século XXI (Vol. 4, pp. 205-238). Belo Horizonte: Editora BDMG.

Lustosa, L., Mesquisa, M. A., Quelhas, O., \& Oliveira, R. J. (2011). Planejamento e controle da produção. Rio de Janeiro: ABEPRO.

Salvador, F. (1999). Projeto de um sistema de refrigeração industrial com "set point" variável (Dissertação de mestrado). Universidade de São Paulo, São Paulo. 
Sarcinelli, M. F., Venturini, K. S., \& Silva, L. C. (2007). Processamento da carne suína. Vitória: UFES.

Shingo, S. (1996). O sistema Toyota de produção do ponto de vista da Engenharia de Produção (2. ed.). Porto Alegre: ARTMED.

Silva, A. L. (2009). Desenvolvimento de um modelo de análise e projeto de layout industrial orientado para a produção enxuta (Tese de doutorado). Escola de Engenharia de São Carlos, Universidade de São Paulo, São Carlos.

Slack, N., Chambers, S., Harland, C., Harrion, A., \& Johnston, R. (1996). Administração da produção. São Paulo: Atlas.

Soares, J. P. M., Lemos, F. O., Araújo, C. L. K., \& Hansen, P. B. (2011). A contribuição da simulação computacional para a análise sistêmica da reestruturação de layout $\mathrm{e}$ otimização de recursos na manufatura celular: estudo de caso em uma célula de uma empresa do ramo automotivo. Produto \& Produção., 12(3), 49-68. http://dx.doi.org/10.22456/1983-8026.22802.

Toledo, I. B., Jr. (2004). Lay-out: arranjo físico (8. ed.). Mogi das Cruzes: O\&M Itys Fides.

Tortorella, G. L. (2006). Sistemática para Orientação do Planejamento de Layout com apoio de análise de decisão multicritério (Dissertação de mestrado). Universidade Federal do Rio Grande do Sul, Porto Alegre.

Vieira, E. T. T. (2007). Influencia do processo de congelamento na qualidade do peito de frango (Dissertação de mestrado). Universidade Regional Integrada do Alto Uruguai, Erechim. 


\section{Appendix A}

Table 1. Temperature Measurements on Track 1.

\begin{tabular}{|c|c|c|c|c|c|c|c|c|c|}
\hline & \multicolumn{9}{|c|}{$\begin{array}{l}\text { Trail: } 1 \text { Date and Time of Arrival: 04/11 to 15:00 } \\
\text { Date and Time of Departure: 05/10 at 02:00 PM Time in the Tunnel: 23:00 }\end{array}$} \\
\hline & \multicolumn{3}{|c|}{ Cage 1 - Position $1^{\mathrm{a}}$} & \multicolumn{3}{|c|}{ Cage 2 - Position $10^{a}$} & \multicolumn{3}{|c|}{ Cage 3 - Position $20^{a}$} \\
\hline & $\begin{array}{l}\text { Higher } \\
\left({ }^{\circ} \mathrm{C}\right)\end{array}$ & $\begin{array}{l}\text { Center } \\
\left({ }^{\circ} \mathrm{C}\right)\end{array}$ & $\begin{array}{l}\text { Inferior } \\
\left({ }^{\circ} \mathrm{C}\right)\end{array}$ & $\begin{array}{l}\text { Higher } \\
\left({ }^{\circ} \mathrm{C}\right)\end{array}$ & $\begin{array}{l}\text { Center } \\
\left({ }^{\circ} \mathrm{C}\right)\end{array}$ & $\begin{array}{l}\text { Inferior } \\
\left({ }^{\circ} \mathrm{C}\right)\end{array}$ & $\begin{array}{l}\text { Higher } \\
\left({ }^{\circ} \mathrm{C}\right)\end{array}$ & $\begin{array}{c}\text { Center } \\
\left({ }^{\circ} \mathrm{C}\right)\end{array}$ & $\begin{array}{l}\text { Inferior } \\
\left({ }^{\circ} \mathrm{C}\right)\end{array}$ \\
\hline $\begin{array}{l}\text { Greater } \\
\text { Side } 1\end{array}$ & -21.7 & -19.9 & -19.5 & -19.2 & -19.0 & -21.4 & -15.6 & -13.6 & -17.0 \\
\hline $\begin{array}{l}\text { Greater } \\
\text { Side } 2\end{array}$ & -21.9 & -19.4 & -19.8 & -18.6 & -17.2 & -19.9 & -16.2 & -14.4 & -17.4 \\
\hline $\begin{array}{l}\text { Small } \\
\text { Side } 1\end{array}$ & -21.4 & -21.9 & -21.5 & -20.3 & -19.0 & -21.3 & -16.3 & -14.6 & -17.8 \\
\hline $\begin{array}{l}\text { Small } \\
\text { Side } 2\end{array}$ & -21.5 & -18.9 & -18.0 & -18.3 & -18.4 & -19.7 & -15.4 & -15.0 & -17.9 \\
\hline Center 1 & -18.3 & -21.0 & -22.9 & -21.4 & -18.8 & -21.4 & -15.7 & -13.0 & -16.6 \\
\hline Center 2 & -21.6 & -20.1 & -23.4 & -19.1 & -18.4 & -21.2 & -15.3 & -13.4 & -17.4 \\
\hline Side 1 & -21.8 & -19.8 & -24.2 & -18.0 & -18.1 & -21.7 & -15.6 & -16.0 & -18.9 \\
\hline Side 2 & -18.0 & -20.8 & -22.8 & -18.2 & -18.5 & -21.0 & -15.8 & -16.0 & -18.4 \\
\hline Side 3 & -20.7 & -20.2 & -22.3 & -19.4 & -18.3 & -21.4 & -16.9 & -14.0 & -17.6 \\
\hline Side 4 & -20.3 & -18.6 & -22.3 & -19.9 & -19.1 & -21.6 & -17.3 & -14.9 & -18.2 \\
\hline
\end{tabular}

Table 2. Temperature Measurements on Track 2.

\begin{tabular}{|c|c|c|c|c|c|c|c|c|c|}
\hline & \multicolumn{9}{|c|}{$\begin{array}{l}\text { Trail: } 2 \text { Date and Time of Arrival: } 10 / 22 \text { to } 17: 10 \\
\text { Date and Time of Departure: } 10 / 23 \text { to } 2: 10 \mathrm{pm} \text { Tunnel Time: 9:00 pm }\end{array}$} \\
\hline & \multicolumn{3}{|c|}{ Cage 1 - Position $1^{a}$} & \multicolumn{3}{|c|}{ Cage 2 - Position $10^{a}$} & \multicolumn{3}{|c|}{ Cage 3 - Position $20^{a}$} \\
\hline & $\begin{array}{l}\text { Higher } \\
\left({ }^{\circ} \mathrm{C}\right)\end{array}$ & $\begin{array}{l}\text { Center } \\
\left({ }^{\circ} \mathrm{C}\right)\end{array}$ & $\begin{array}{l}\text { Inferior } \\
\left({ }^{\circ} \mathrm{C}\right)\end{array}$ & $\begin{array}{l}\text { Higher } \\
\left({ }^{\circ} \mathrm{C}\right)\end{array}$ & $\begin{array}{l}\text { Center } \\
\left({ }^{\circ} \mathrm{C}\right)\end{array}$ & $\begin{array}{l}\text { Inferior } \\
\left({ }^{\circ} \mathrm{C}\right)\end{array}$ & $\begin{array}{l}\text { Higher } \\
\left({ }^{\circ} \mathrm{C}\right)\end{array}$ & $\begin{array}{l}\text { Center } \\
\left({ }^{\circ} \mathrm{C}\right)\end{array}$ & $\begin{array}{l}\text { Inferior } \\
\left({ }^{\circ} \mathrm{C}\right)\end{array}$ \\
\hline $\begin{array}{l}\text { Greater } \\
\text { Side } 1\end{array}$ & -16.1 & -18.3 & -20.2 & -7.2 & -6.9 & -6.2 & -9.4 & -6.7 & -10.0 \\
\hline $\begin{array}{l}\text { Greater } \\
\text { Side } 2\end{array}$ & -17.6 & -16.4 & -19.1 & -5.4 & -5.0 & -9.3 & -12.1 & -7.6 & -10.3 \\
\hline $\begin{array}{l}\text { Small } \\
\text { Side } 1\end{array}$ & -18.5 & -19.0 & -20.2 & -8.4 & -6.0 & -8.0 & -12.1 & -6.1 & -12.2 \\
\hline $\begin{array}{l}\text { Small } \\
\text { Side } 2\end{array}$ & -15.4 & -14.9 & -16.4 & -9.2 & -6.6 & -9.5 & -12.9 & -5.8 & -10.6 \\
\hline Center 1 & -18.6 & -17.5 & -18.3 & -6.3 & -5.0 & -4.5 & -11.2 & -5.1 & -7.3 \\
\hline Center 2 & -17.2 & -18.7 & -20.0 & -6.3 & -4.0 & -6.1 & -9.0 & -4.0 & -10.0 \\
\hline Side 1 & -17.1 & -18.5 & -21.0 & -10.0 & -8.1 & -11.5 & -13.4 & -9.7 & -11.0 \\
\hline Side 2 & -19.4 & -17.4 & -19.4 & -10.0 & -7.4 & -9.2 & -12.4 & -9.0 & -10.5 \\
\hline Side 3 & -19.1 & -17.5 & -19.5 & -7.5 & -7.0 & -10.1 & -11.3 & -7.0 & -12.7 \\
\hline Side 4 & -17.9 & -16.6 & -19.2 & -10.0 & -11.1 & -12.9 & -13.1 & -7.6 & -12.5 \\
\hline
\end{tabular}


Table 3. Temperature Measurements on Track 3.

\begin{tabular}{|c|c|c|c|c|c|c|c|c|c|}
\hline & \multicolumn{9}{|c|}{$\begin{array}{l}\text { Trail: } 3 \text { Date and Time of Arrival: } 10 / 22 \text { to } 4: 25 \text { PM } \\
\text { Date and Time of Departure: } 10 / 23 \text { to } 1: 15 \text { pm Tunnel Time: } 21: 40\end{array}$} \\
\hline & \multicolumn{3}{|c|}{ Cage 1 - Position $1^{a}$} & \multicolumn{3}{|c|}{ Cage 2 - Position $10^{a}$} & \multicolumn{3}{|c|}{ Cage 3 - Position $20^{a}$} \\
\hline & $\begin{array}{l}\text { Higher } \\
\left({ }^{\circ} \mathrm{C}\right)\end{array}$ & $\begin{array}{c}\text { Center } \\
\left({ }^{\circ} \mathrm{C}\right)\end{array}$ & $\begin{array}{l}\text { Inferio } \\
\mathrm{r}\left({ }^{\circ} \mathrm{C}\right)\end{array}$ & $\begin{array}{l}\text { Higher } \\
\left({ }^{\circ} \mathrm{C}\right)\end{array}$ & $\begin{array}{c}\text { Center } \\
\left({ }^{\circ} \mathrm{C}\right)\end{array}$ & $\begin{array}{l}\text { Inferio } \\
\mathrm{r}\left({ }^{\circ} \mathrm{C}\right)\end{array}$ & $\begin{array}{l}\text { Higher } \\
\left({ }^{\circ} \mathrm{C}\right)\end{array}$ & $\begin{array}{c}\text { Center } \\
\left({ }^{\circ} \mathrm{C}\right)\end{array}$ & $\begin{array}{l}\text { Inferio } \\
\mathrm{r}\left({ }^{\circ} \mathrm{C}\right)\end{array}$ \\
\hline $\begin{array}{l}\text { Greater } \\
\text { Side } 1\end{array}$ & -16.1 & -16.9 & -6.5 & -14.5 & -7.6 & -14.0 & -13.0 & -12.0 & -11.3 \\
\hline $\begin{array}{l}\text { Greater } \\
\text { Side } 2\end{array}$ & -16.5 & -13.0 & -3.1 & -15.5 & -15.3 & -14.3 & -12.3 & -13.3 & -15.9 \\
\hline $\begin{array}{l}\text { Small } \\
\text { Side } 1\end{array}$ & -13.5 & -12.4 & -16.4 & -15.4 & -6.3 & -18.0 & -14.8 & -15.6 & -12.3 \\
\hline $\begin{array}{l}\text { Small } \\
\text { Side } 2\end{array}$ & -11.6 & -12.4 & -17.1 & -17.1 & -12.3 & -13.7 & -12.8 & -13.4 & -9.0 \\
\hline Center 1 & -17.5 & -14.3 & -11.5 & -14.4 & -15.3 & -10.7 & -10.7 & -13.5 & -20.7 \\
\hline Center 2 & -24.5 & -13.4 & -12.1 & -16.0 & -9.0 & -9.0 & -6.2 & -13.4 & -20.0 \\
\hline Side 1 & -15.6 & -18.4 & -14.3 & -15.1 & -13.0 & -16.2 & -11.5 & -14.5 & -20.3 \\
\hline Side 2 & -17.3 & -12.0 & -10.7 & -17.3 & -13.9 & -17.3 & -15.6 & -12.4 & -13.6 \\
\hline Side 3 & -15.3 & -15.3 & -7.3 & -17.3 & -14.6 & -16.8 & -11.0 & -14.7 & -16.4 \\
\hline Side 4 & -23.9 & -13.1 & -16.1 & -14.3 & -13.9 & -13.9 & -14.4 & -13.8 & -16.1 \\
\hline
\end{tabular}

Table 4. Temperature Measurements on Track 4.

\begin{tabular}{|c|c|c|c|c|c|c|c|c|c|}
\hline & \multicolumn{9}{|c|}{$\begin{array}{l}\text { Trail: } 4 \text { Date and Time of Arrival: } 10 / 28 \text { at } 13: 10 \\
\text { Date and Time of Exit: } 29 / 10 \text { to } 09: 10 \text { Time in the Tunnel: } 19: 20\end{array}$} \\
\hline & \multicolumn{3}{|c|}{ Cage 1 - Position $1^{a}$} & \multicolumn{3}{|c|}{ Cage 2 - Position $10^{a}$} & \multicolumn{3}{|c|}{ Cage 3 - Position $20^{a}$} \\
\hline & $\begin{array}{l}\text { Higher } \\
\left({ }^{\circ} \mathrm{C}\right)\end{array}$ & $\begin{array}{c}\text { Center } \\
\left({ }^{\circ} \mathrm{C}\right)\end{array}$ & $\begin{array}{l}\text { Inferior } \\
\left({ }^{\circ} \mathrm{C}\right)\end{array}$ & $\begin{array}{l}\text { Higher } \\
\left({ }^{\circ} \mathrm{C}\right)\end{array}$ & $\begin{array}{c}\text { Center } \\
\left({ }^{\circ} \mathrm{C}\right)\end{array}$ & $\begin{array}{l}\text { Inferior } \\
\left({ }^{\circ} \mathrm{C}\right)\end{array}$ & $\begin{array}{l}\text { Higher } \\
\left({ }^{\circ} \mathrm{C}\right)\end{array}$ & $\begin{array}{c}\text { Center } \\
\left({ }^{\circ} \mathrm{C}\right)\end{array}$ & $\begin{array}{c}\text { Inferior } \\
\left({ }^{\circ} \mathrm{C}\right)\end{array}$ \\
\hline $\begin{array}{l}\text { Greater } \\
\text { Side } 1\end{array}$ & -20.6 & -16.0 & -17.4 & -16.9 & -13.0 & -14.0 & -16.2 & -12.2 & -14.0 \\
\hline $\begin{array}{l}\text { Greater } \\
\text { Side } 2\end{array}$ & -19.0 & -14.5 & -12.4 & -14.0 & -11.3 & -16.0 & -14.1 & -12.0 & -14.0 \\
\hline $\begin{array}{l}\text { Small } \\
\text { Side } 1\end{array}$ & -15.5 & -16.0 & -14.0 & -18.4 & -16.3 & -15.9 & -18.5 & -13.5 & -15.3 \\
\hline $\begin{array}{l}\text { Small } \\
\text { Side } 2\end{array}$ & -18.3 & -15.3 & -15.6 & -16.4 & -12.0 & -12.0 & -14.6 & -13.2 & -15.4 \\
\hline Center 1 & -19.7 & -18.1 & -22.0 & -18.3 & -12.5 & -17.0 & -14.0 & -12.8 & -13.9 \\
\hline Center 2 & -19.7 & -16.2 & -19.0 & -18.0 & -14.6 & -17.0 & -17.1 & -10.8 & -15.6 \\
\hline Side 1 & -20.2 & -17.3 & -18.3 & -18.0 & -13.2 & -17.6 & -14.9 & -14.0 & -16.3 \\
\hline Side 2 & -18.2 & -16.0 & -16.6 & -19.9 & -13.9 & -19.0 & -16.0 & -15.4 & -16.0 \\
\hline Side 3 & -18.3 & -17.5 & -18.9 & -19.4 & -15.9 & -18.0 & -16.0 & -14.7 & -14.0 \\
\hline Side 4 & -19.9 & -18.0 & -19.0 & -17.3 & -17.3 & -18.0 & -15.5 & -12.8 & -15.3 \\
\hline
\end{tabular}


Table 5.Temperature Measurements on Track 5.

\begin{tabular}{|c|c|c|c|c|c|c|c|c|c|}
\hline & \multicolumn{9}{|c|}{$\begin{array}{l}\text { Trail: } 5 \text { Date and Time of Arrival: } 09 / 11 \text { at } 11 \mathrm{~h} 50 \mathrm{~min} \\
\text { Date and Time of Departure: } 10 / 11 \text { to } 04 \mathrm{~h} 00 \mathrm{~min} \text { Tunnel Time: } 15 \mathrm{~h} 50 \mathrm{~min}\end{array}$} \\
\hline & \multicolumn{3}{|c|}{ Cage 1 - Position $1^{a}$} & \multicolumn{3}{|c|}{ Cage 2 - Position $10^{a}$} & \multicolumn{3}{|c|}{ Cage 3 - Position $20^{a}$} \\
\hline & $\begin{array}{c}\text { Higher } \\
\left({ }^{\circ} \mathrm{C}\right)\end{array}$ & $\begin{array}{c}\text { Center } \\
\left({ }^{\circ} \mathrm{C}\right)\end{array}$ & $\begin{array}{c}\text { Inferior } \\
\left({ }^{\circ} \mathrm{C}\right)\end{array}$ & $\begin{array}{c}\text { Higher } \\
\left({ }^{\circ} \mathrm{C}\right)\end{array}$ & $\begin{array}{l}\text { Center } \\
\left({ }^{\circ} \mathrm{C}\right)\end{array}$ & $\begin{array}{l}\text { Inferior } \\
\left({ }^{\circ} \mathrm{C}\right)\end{array}$ & $\begin{array}{c}\text { Higher } \\
\left({ }^{\circ} \mathrm{C}\right)\end{array}$ & $\begin{array}{c}\text { Center } \\
\left({ }^{\circ} \mathrm{C}\right)\end{array}$ & $\begin{array}{c}\text { Inferior } \\
\left({ }^{\circ} \mathrm{C}\right)\end{array}$ \\
\hline $\begin{array}{l}\text { Greater } \\
\text { Side } 1\end{array}$ & -17.0 & -18.3 & -17.8 & -18.4 & -15.4 & -16.6 & -19.4 & -13.9 & -17.3 \\
\hline $\begin{array}{l}\text { Greater } \\
\text { Side } 2\end{array}$ & -18.2 & -15.3 & -12.3 & -18.7 & -15.6 & -15.2 & -19.2 & -15.1 & -16.9 \\
\hline $\begin{array}{l}\text { Small } \\
\text { Side } 1\end{array}$ & -17.6 & -14.9 & -18.2 & -19.1 & -15.0 & -16.4 & -18.5 & -14.0 & -17.2 \\
\hline $\begin{array}{l}\text { Small } \\
\text { Side } 2\end{array}$ & -18.1 & -12.9 & -13.8 & -18.9 & -18.4 & -14.8 & -20.1 & -13.2 & -16.8 \\
\hline Center 1 & -20.9 & -16.0 & -15.6 & -19.9 & -16.8 & -16.3 & -20.0 & -12.5 & -16.4 \\
\hline Center 2 & -19.4 & -20.0 & -19.8 & -19.1 & -17.1 & -15.8 & -19.9 & -12.9 & -18.0 \\
\hline Side 1 & -18.8 & -16.4 & -20.3 & -19.3 & -16.1 & -16.2 & -18.3 & -13.0 & -18.1 \\
\hline Side 2 & -17.9 & -20.0 & -20.7 & -18.4 & -17.2 & -14.8 & -17.9 & -12.7 & -17.6 \\
\hline Side 3 & -16.0 & -20.0 & -20.0 & -19.5 & -16.7 & -15.3 & -19.2 & -12.8 & -17.2 \\
\hline Side 4 & -14.7 & -12.4 & -22.0 & -19.2 & -16.9 & -16.1 & -18.4 & -12.7 & -18.1 \\
\hline
\end{tabular}

Table 6.Temperature Measurements on Track 6.

Trail: 6 Date and Time of Arrival: 11/11 to 05:30

Date and Time of Departure: $11 / 11$ to $15: 40$ Time in the Tunnel: $10 \mathrm{~h} 10 \mathrm{~min}$

\begin{tabular}{|c|c|c|c|c|c|c|c|c|c|}
\hline & \multicolumn{3}{|c|}{ Cage 1 - Position $1^{a}$} & \multicolumn{3}{|c|}{ Cage 2 - Position $10^{a}$} & \multicolumn{3}{|c|}{ Cage 3 - Position 20a } \\
\hline & $\begin{array}{l}\text { Higher } \\
\left({ }^{\circ} \mathrm{C}\right)\end{array}$ & $\begin{array}{c}\text { Center } \\
\left({ }^{\circ} \mathrm{C}\right)\end{array}$ & $\begin{array}{l}\text { Inferio } \\
\mathrm{r}\left({ }^{\circ} \mathrm{C}\right)\end{array}$ & $\begin{array}{l}\text { Higher } \\
\left({ }^{\circ} \mathrm{C}\right)\end{array}$ & $\begin{array}{l}\text { Center } \\
\left({ }^{\circ} \mathrm{C}\right)\end{array}$ & $\begin{array}{l}\text { Inferio } \\
\mathrm{r}\left({ }^{\circ} \mathrm{C}\right)\end{array}$ & $\begin{array}{l}\text { Higher } \\
\left({ }^{\circ} \mathrm{C}\right)\end{array}$ & $\begin{array}{c}\text { Center } \\
\left({ }^{\circ} \mathrm{C}\right)\end{array}$ & $\begin{array}{l}\text { Inferio } \\
r\left({ }^{\circ} \mathrm{C}\right)\end{array}$ \\
\hline $\begin{array}{l}\text { Greater } \\
\text { Side } 1\end{array}$ & -9.3 & -6.3 & -11.2 & -15.3 & -11.6 & -9.1 & -13.6 & -13.4 & -6.0 \\
\hline $\begin{array}{l}\text { Greater } \\
\text { Side } 2\end{array}$ & -13.2 & -7.4 & -7.0 & -14.3 & -10.2 & -16.3 & -13.1 & -14.2 & -11.3 \\
\hline $\begin{array}{l}\text { Small } \\
\text { Side } 1\end{array}$ & -13.6 & -5.6 & -15.3 & -15.6 & -6.3 & -14.0 & -13.6 & -15.8 & -14.8 \\
\hline $\begin{array}{l}\text { Small } \\
\text { Side } 2\end{array}$ & -9.2 & -7.1 & -24.4 & -13.2 & -9.0 & -16.1 & -9.8 & -4.0 & -15.2 \\
\hline Center 1 & -3.4 & -6.4 & -22.6 & -5.7 & -8.0 & -11.3 & -10.8 & -4.1 & -7.0 \\
\hline Center 2 & -6.7 & -7.5 & -10.8 & -10.2 & -5.0 & -13.0 & -11.7 & -13.6 & -10.7 \\
\hline Side 1 & -18.5 & -17.8 & -7.9 & -18.5 & -14.8 & -21.9 & -12.6 & -16.3 & -18.3 \\
\hline Side 2 & -17.2 & -19.7 & -12.4 & -19.3 & -16.1 & -23.8 & -13.7 & -15.3 & -15.2 \\
\hline Side 3 & -15.7 & -21.1 & -11.7 & -20.0 & -18.7 & -19.6 & -15.2 & -15.4 & -14.6 \\
\hline Side 4 & -16.2 & -20.6 & -13.1 & -21.2 & -15.3 & -18.9 & -14.4 & -15.6 & -13.4 \\
\hline
\end{tabular}


Table 7. Temperature Measurements on Track 7.

\begin{tabular}{|c|c|c|c|c|c|c|c|c|c|}
\hline & \multicolumn{9}{|c|}{$\begin{array}{l}\text { Trail: } 7 \text { Date and Time of Arrival: } 10 / 26 \text { to } 07: 15 \\
\text { Date and Time of Departure: } 10 / 27 \text { to } 07: 20 \text { PM Tunnel Time: } 24 \mathrm{~h} 05 \mathrm{~min}\end{array}$} \\
\hline & \multicolumn{3}{|c|}{ Cage 1 - Position $1^{\mathrm{a}}$} & \multicolumn{3}{|c|}{ Cage 2 - Position $10^{a}$} & \multicolumn{3}{|c|}{ Cage 3 - Position $20^{a}$} \\
\hline & $\begin{array}{l}\text { Higher } \\
\left({ }^{\circ} \mathrm{C}\right)\end{array}$ & $\begin{array}{c}\text { Center } \\
\left({ }^{\circ} \mathrm{C}\right)\end{array}$ & $\begin{array}{l}\text { Inferior } \\
\left({ }^{\circ} \mathrm{C}\right)\end{array}$ & $\begin{array}{l}\text { Higher } \\
\left({ }^{\circ} \mathrm{C}\right)\end{array}$ & $\begin{array}{l}\text { Center } \\
\left({ }^{\circ} \mathrm{C}\right)\end{array}$ & $\begin{array}{l}\text { Inferior } \\
\left({ }^{\circ} \mathrm{C}\right)\end{array}$ & $\begin{array}{l}\text { Higher } \\
\left({ }^{\circ} \mathrm{C}\right)\end{array}$ & $\begin{array}{l}\text { Center } \\
\left({ }^{\circ} \mathrm{C}\right)\end{array}$ & $\begin{array}{l}\text { Inferior } \\
\left({ }^{\circ} \mathrm{C}\right)\end{array}$ \\
\hline $\begin{array}{l}\text { Greater } \\
\text { Side } 1\end{array}$ & -16.1 & -16.9 & -6.5 & -14.5 & -7.6 & -14.0 & -13.0 & -12.0 & -11.3 \\
\hline $\begin{array}{l}\text { Greater } \\
\text { Side } 2\end{array}$ & -16.5 & -13.0 & -3.1 & -15.5 & -15.3 & -14.3 & -12.3 & -13.3 & -15.9 \\
\hline $\begin{array}{l}\text { Small } \\
\text { Side } 1\end{array}$ & -13.5 & -12.4 & -16.4 & -15.4 & -6.3 & -18.0 & -14.8 & -15.6 & -12.3 \\
\hline $\begin{array}{l}\text { Small } \\
\text { Side } 2\end{array}$ & -11.6 & -12.4 & -17.1 & -17.1 & -12.3 & -13.7 & -12.8 & -13.4 & -9.0 \\
\hline Center 1 & -17.5 & -14.3 & -11.5 & -14.1 & -15.3 & -10.7 & -10.7 & -13.5 & -20.7 \\
\hline Center 2 & -24.5 & -13.4 & -12.1 & -16.0 & -9.0 & -9.0 & -6.2 & -13.4 & -20.0 \\
\hline Side 1 & -15.6 & -18.4 & -14.3 & -15.1 & -13.0 & -16.2 & -11.5 & -14.5 & -20.3 \\
\hline Side 2 & -17.3 & -12.0 & -10.7 & -17.3 & -13.9 & -17.3 & -15.6 & -12.4 & -13.6 \\
\hline Side 3 & -15.3 & -15.3 & -7.3 & -17.3 & -14.6 & -16.8 & -11.0 & -14.7 & -16.4 \\
\hline Side 4 & -23.9 & -13.1 & -16.1 & -14.3 & -13.3 & -13.9 & -14.4 & -13.8 & -16.1 \\
\hline
\end{tabular}

Table 8. Temperature Measurements on Track 8.

Trail: 8 Date and Time of Arrival: 10/28 to 9:10 PM Date and Time of Departure: 10/29 to 8:30 AM Tunnel Time: 10:40 a.m.

\begin{tabular}{|c|c|c|c|c|c|c|c|c|c|}
\hline & \multicolumn{3}{|c|}{ Cage 1 - Position $1^{a}$} & \multicolumn{3}{|c|}{ Cage 2 - Position $10^{a}$} & \multicolumn{3}{|c|}{ Cage 3 - Position $20^{a}$} \\
\hline & $\begin{array}{l}\text { Higher } \\
\left({ }^{\circ} \mathrm{C}\right)\end{array}$ & $\begin{array}{l}\text { Center } \\
\left({ }^{\circ} \mathrm{C}\right)\end{array}$ & $\begin{array}{c}\text { Inferior } \\
\left({ }^{\circ} \mathrm{C}\right)\end{array}$ & $\begin{array}{l}\text { Higher } \\
\left({ }^{\circ} \mathrm{C}\right)\end{array}$ & $\begin{array}{l}\text { Center } \\
\left({ }^{\circ} \mathrm{C}\right)\end{array}$ & $\begin{array}{c}\text { Inferior } \\
\left({ }^{\circ} \mathrm{C}\right)\end{array}$ & $\begin{array}{l}\text { Higher } \\
\left({ }^{\circ} \mathrm{C}\right)\end{array}$ & $\begin{array}{l}\text { Center } \\
\left({ }^{\circ} \mathrm{C}\right)\end{array}$ & $\begin{array}{l}\text { Inferior } \\
\left({ }^{\circ} \mathrm{C}\right)\end{array}$ \\
\hline $\begin{array}{l}\text { Greater } \\
\text { Side } 1\end{array}$ & -17.7 & -19.5 & -18.3 & -17.2 & -17.2 & -18.0 & -6.6 & -8.2 & -8.6 \\
\hline $\begin{array}{l}\text { Greater } \\
\text { Side } 2\end{array}$ & -16.3 & -13.6 & -14.6 & -13.3 & -12.8 & -16.0 & -4.6 & -7.3 & -9.0 \\
\hline $\begin{array}{l}\text { Small } \\
\text { Side } 1\end{array}$ & -18.0 & -18.1 & -20.4 & -17.6 & -16.2 & -16.3 & -3.1 & -10.0 & -6.0 \\
\hline $\begin{array}{l}\text { Small } \\
\text { Side } 2\end{array}$ & -17.8 & -19.0 & -19.4 & -16.2 & -14.7 & -18.6 & -8.7 & -8.8 & -8.0 \\
\hline Center 1 & -18.2 & -14.4 & -17.3 & -16.6 & -12.0 & -15.4 & -4.8 & -7.4 & -6.0 \\
\hline Center 2 & -18.4 & -18.3 & -16.0 & -15.9 & -14.6 & -13.8 & -3.7 & -8.0 & -5.9 \\
\hline Side 1 & -20.6 & -19.8 & -19.2 & -17.0 & -16.1 & -15.5 & -11.9 & -10.0 & -9.0 \\
\hline Side 2 & -18.4 & -20.1 & -19.8 & -18.7 & -17.0 & -15.6 & -6.7 & -10.3 & -14.3 \\
\hline Side 3 & -17.2 & -19.7 & -20.8 & -16.6 & -16.0 & -21.6 & -8.5 & -11.2 & -9.3 \\
\hline Side 4 & -19.0 & -18.4 & -18.7 & -17.9 & -15.5 & -17.0 & -8.0 & -3.0 & -7.8 \\
\hline
\end{tabular}


Table 9.Temperature Measurements on Track 9.

\begin{tabular}{|c|c|c|c|c|c|c|c|c|c|}
\hline & \multicolumn{9}{|c|}{$\begin{array}{l}\text { Trail: } 9 \text { Date and Time of Arrival: } 10 / 29 \text { at } 11: 50 \\
\text { Date and Time of Departure: } 10 / 30 \text { to } 8: 30 \text { am Time in the Tunnel: } 9: 20 \mathrm{pm}\end{array}$} \\
\hline & \multicolumn{3}{|c|}{ Cage 1 - Position $1^{\mathrm{a}}$} & \multicolumn{3}{|c|}{ Cage 2 - Position $10^{a}$} & \multicolumn{3}{|c|}{ Cage 3 - Position 20a } \\
\hline & $\begin{array}{l}\text { Higher } \\
\left({ }^{\circ} \mathrm{C}\right)\end{array}$ & $\begin{array}{c}\text { Center } \\
\left({ }^{\circ} \mathrm{C}\right)\end{array}$ & $\begin{array}{l}\text { Inferior } \\
\left({ }^{\circ} \mathrm{C}\right)\end{array}$ & $\begin{array}{l}\text { Higher } \\
\left({ }^{\circ} \mathrm{C}\right)\end{array}$ & $\begin{array}{c}\text { Center } \\
\left({ }^{\circ} \mathrm{C}\right)\end{array}$ & $\begin{array}{l}\text { Inferior } \\
\left({ }^{\circ} \mathrm{C}\right)\end{array}$ & $\begin{array}{l}\text { Higher } \\
\left({ }^{\circ} \mathrm{C}\right)\end{array}$ & $\begin{array}{c}\text { Center } \\
\left({ }^{\circ} \mathrm{C}\right)\end{array}$ & $\begin{array}{l}\text { Inferior } \\
\left({ }^{\circ} \mathrm{C}\right)\end{array}$ \\
\hline $\begin{array}{l}\text { Greater } \\
\text { Side } 1\end{array}$ & -19.5 & -18.2 & -19.1 & -19.5 & -12.8 & -19.1 & -16.9 & -13.0 & -14.0 \\
\hline $\begin{array}{l}\text { Greater } \\
\text { Side } 2\end{array}$ & -21.4 & -17.2 & -17.5 & -18.4 & -12.0 & -18.3 & -14.0 & -11.3 & -16.0 \\
\hline $\begin{array}{l}\text { Small } \\
\text { Side } 1\end{array}$ & -22.0 & -17.9 & -22.3 & -17.5 & -14.2 & -20.3 & -18.4 & -16.3 & -15.9 \\
\hline $\begin{array}{l}\text { Small } \\
\text { Side } 2\end{array}$ & -19.9 & -16.2 & -19.4 & -22.9 & -14.8 & -17.7 & -16.4 & -12.0 & -12.0 \\
\hline Center 1 & -22.7 & -12.9 & -17.0 & -21.3 & -13.7 & -17.7 & -18.3 & -12.5 & -17.0 \\
\hline Center 2 & -21.1 & -18.0 & -20.0 & -22.9 & -12.9 & -19.8 & -18.0 & -14.6 & -17.0 \\
\hline Side 1 & -20.0 & -19.6 & -20.5 & -19.1 & -16.0 & -22.4 & -18.0 & -13.2 & -17.6 \\
\hline Side 2 & -19.4 & -19.3 & -19.9 & -21.5 & -12.4 & -21.7 & -19.9 & -13.9 & -19.0 \\
\hline Side 3 & -21.4 & -18.3 & -23.1 & -21.4 & -15.4 & -22.1 & -19.4 & -15.9 & -18.0 \\
\hline Side 4 & -22.8 & -17.4 & -20.7 & -24.4 & -14.2 & -21.0 & -17.3 & -17.3 & -18.0 \\
\hline
\end{tabular}

Table 10. Temperature Measurements on Track 10.

Trail: 10 Date and Time of Arrival: 09/11 at 10:00 p.m.

Date and Time of Departure: 10/11 to 11:30 AM Tunnel Time: 13:30

\begin{tabular}{|c|c|c|c|c|c|c|c|c|c|}
\hline & \multicolumn{3}{|c|}{ Cage 1 - Position $1^{a}$} & \multicolumn{3}{|c|}{ Cage 2 - Position $10^{a}$} & \multicolumn{3}{|c|}{ Cage 3 - Position $20^{a}$} \\
\hline & $\begin{array}{l}\text { Higher } \\
\left({ }^{\circ} \mathrm{C}\right)\end{array}$ & $\begin{array}{c}\text { Center } \\
\left({ }^{\circ} \mathrm{C}\right)\end{array}$ & $\begin{array}{c}\text { Inferior } \\
\left({ }^{\circ} \mathrm{C}\right)\end{array}$ & $\begin{array}{l}\text { Higher } \\
\left({ }^{\circ} \mathrm{C}\right)\end{array}$ & $\begin{array}{c}\text { Center } \\
\left({ }^{\circ} \mathrm{C}\right)\end{array}$ & $\begin{array}{l}\text { Inferior } \\
\left({ }^{\circ} \mathrm{C}\right)\end{array}$ & $\begin{array}{l}\text { Higher } \\
\left({ }^{\circ} \mathrm{C}\right)\end{array}$ & $\begin{array}{c}\text { Center } \\
\left({ }^{\circ} \mathrm{C}\right)\end{array}$ & $\begin{array}{l}\text { Inferior } \\
\left({ }^{\circ} \mathrm{C}\right)\end{array}$ \\
\hline $\begin{array}{l}\text { Greater } \\
\text { Side } 1\end{array}$ & -19.0 & -17.1 & -13.5 & -15.1 & -16.4 & -13.0 & -16.8 & -17.7 & -16.6 \\
\hline $\begin{array}{l}\text { Greater } \\
\text { Side } 2\end{array}$ & -18.1 & -17.3 & -13.9 & -16.4 & -16.1 & -13.1 & -17.1 & -18.2 & -17.1 \\
\hline $\begin{array}{l}\text { Small } \\
\text { Side } 1\end{array}$ & -17.1 & -17.3 & -16.4 & -15.4 & -16.7 & -14.6 & -16.4 & -17.4 & -17.9 \\
\hline $\begin{array}{l}\text { Small } \\
\text { Side } 2\end{array}$ & -19.1 & -17.4 & -13.0 & -16.5 & -15.9 & -12.3 & -16.8 & -16.2 & -18.0 \\
\hline Center 1 & -17.7 & -16.9 & -13.1 & -16.4 & -15.6 & -5.7 & -17.7 & -19.1 & -22.4 \\
\hline Center 2 & -17.4 & -17.4 & -17.1 & -15.5 & -13.5 & -9.7 & -17.9 & -15.9 & -18.6 \\
\hline Side 1 & -16.7 & -17.3 & -16.3 & -17.0 & -15.3 & -12.2 & -17.1 & -16.1 & -17.2 \\
\hline Side 2 & -18.1 & -16.9 & -15.9 & -16.4 & -14.4 & -13.1 & -17.4 & -15.6 & -16.9 \\
\hline Side 3 & -16.5 & -17.4 & -15.9 & -17.1 & -14.7 & -12.4 & -16.9 & -16.2 & -17.5 \\
\hline Side 4 & -17.1 & -17.1 & -17.1 & -16.3 & -15.5 & -12.9 & -16.8 & -17.1 & -17.8 \\
\hline
\end{tabular}

